Review

\title{
Calcium Regulation and Bone Mineral Metabolism in Elderly Patients with Chronic Kidney Disease
}

\section{Vickram Tejwani and Qi Qian *}

Division of Nephrology, Department of Medicine, Mayo Clinic College of Medicine, Rochester, MN 55905, USA; E-Mail: tejwani.vickram@mayo.edu

* Author to whom correspondence should be addressed; E-Mail: qian.qi@mayo.edu;

Tel.: +1-507-266-7960; Fax: +1-507-266-7891.

Received: 18 February 2013; in revised form: 25 April 2013 / Accepted: 8 May 2013 /

Published: 29 May 2013

\begin{abstract}
The elderly chronic kidney disease (CKD) population is growing. Both aging and $\mathrm{CKD}$ can disrupt calcium $\left(\mathrm{Ca}^{2+}\right)$ homeostasis and cause alterations of multiple $\mathrm{Ca}^{2+}$-regulatory mechanisms, including parathyroid hormone, vitamin $\mathrm{D}$, fibroblast growth factor-23/Klotho, calcium-sensing receptor and $\mathrm{Ca}^{2+}$-phosphate product. These alterations can be deleterious to bone mineral metabolism and soft tissue health, leading to metabolic bone disease and vascular calcification and aging, termed CKD-mineral and bone disorder (MBD). CKD-MBD is associated with morbid clinical outcomes, including fracture, cardiovascular events and all-cause mortality. In this paper, we comprehensively review $\mathrm{Ca}^{2+}$ regulation and bone mineral metabolism, with a special emphasis on elderly CKD patients. We also present the current treatment-guidelines and management options for CKD-MBD.
\end{abstract}

Keywords: calcium homeostasis; aging; chronic kidney disease; mineral and bone disorder; vascular calcification; secondary hyperparathyroidism

\section{Introduction}

Defects in calcium $\left(\mathrm{Ca}^{2+}\right)$ homeostasis and bone mineral metabolism are major causes of morbidity and mortality in elderly chronic kidney disease (CKD) patients, a steadily growing population worldwide [1]. In this paper, the role of $\mathrm{Ca}^{2+}$ and its dysregulation in elderly CKD is given special consideration, incorporating the most recent advances in pathophysiology. We describe (1) the 
physiology of $\mathrm{Ca}^{2+}$ homeostasis, (2) $\mathrm{CKD}$-associated $\mathrm{Ca}^{2+}$ and bone mineral dysregulation and (3) treatment-guidelines and therapeutic options for elderly CKD patients. It serves as a useful reference for healthcare providers caring for CKD patients. Clear understanding of the pathophysiology and appropriate management of elderly CKD patients can reduce morbidity and mortality.

\section{Calcium Homeostasis and Defects in Aging and CKD}

The average daily diet of a normal adult contains roughly $1000 \mathrm{mg}$ of $\mathrm{Ca}^{2+}$. Approximately $300 \mathrm{mg}$ of ingested $\mathrm{Ca}^{2+}$ is absorbed from the intestine, promoted by vitamin D [2]. In the circulation, $\mathrm{Ca}^{2+}$ exists in three forms: ionized $\left(\sim 51 \%, \mathrm{Ca}^{2+}\right)$, protein-bound $(\sim 40 \%$, primarily albumin-bound) and complexed $(\sim 10 \%)$; the ionized portion is functional [2]. The protein-bound portion can be influenced by blood $\mathrm{pH}$ : increased by alkalemia and reduced by acidemia. Bone mineral metabolism influences $\mathrm{Ca}^{2+}$ concentration by releasing or absorbing circulating $\mathrm{Ca}^{2+}$. When in balance, bone $\mathrm{Ca}^{2+}$ absorption equals bone $\mathrm{Ca}^{2+}$ resorption; hence, absorbed dietary $\mathrm{Ca}^{2+}$ is excreted by both the colon ( $\sim 100-150 \mathrm{mg} /$ day) and kidneys ( $\sim 150-200 \mathrm{mg} /$ day).

In the kidney, $\mathrm{Ca}^{2+}$ is freely filtered through the glomeruli. Fifty to $60 \%$ of filtered $\mathrm{Ca}^{2+}$ is reabsorbed in the proximal tubule via the paracellular pathway coupled to sodium reabsorption (Figure 1A). The reabsorption is enhanced by volume contraction and reduced by volume expansion [3]. Thirty to $35 \%$ of filtered $\mathrm{Ca}^{2+}$ is reabsorbed in the thick ascending limb of the loop of Henle via the paracellular pathway (Figure 1B) [4]. In this segment, serum $\mathrm{Ca}^{2+}$, loop diuretics and the claudin family of proteins influence $\mathrm{Ca}^{2+}$ reabsorption. Hypercalcemia activates the basolateral calcium-sensing receptor (CSR) inhibiting potassium excretion via the renal outer medullary potassium channel (ROMK), diminishing the positive luminal potential, leading to reduction in $\mathrm{Ca}^{2+}$ (and magnesium) reabsorption (reviewed in [5]). Loop diuretics inhibit sodium-potassium-chloride $\left(\mathrm{NKCl}_{2}\right)$ cotransporter, reducing ROMK-mediated potassium exit, thereby diminishing $\mathrm{Ca} 2+$ (and magnesium) reabsorption. Claudin-16 and claudin-19 reside in the paracellular space and facilitate $\mathrm{Ca}^{2+}$ reabsorption. Mutations in these proteins impair $\mathrm{Ca}^{2+}$ reabsorption and cause the autosomal recessive familial hypomagnesemia with hypercalciuria and nephrocalcinosis [6]. The remaining $10 \%$ of the filtered $\mathrm{Ca}^{2+}$ is reabsorbed at the distal renal tubules through a transcellular mechanism (Figure 1C) [3]. TRPV5, a subfamily V member of the transient receptor potential (TRP) cation channels, acts as the luminal-surface $\mathrm{Ca}^{2+}$ receptor [7]. TRPV5-mediated $\mathrm{Ca}^{2+}$ influx is promoted by Klotho (an anti-aging molecule, Box 1) [8,9] and $\mathrm{Ca}^{2+}$ exits via basolateral plasma membrane calcium ATPase (PMCA). CSR activation inhibits PMCA activity, thereby inhibiting transcellular $\mathrm{Ca}^{2+}$ reabsorption [10]. Through a yet to be fully elucidated mechanism, $\mathrm{Ca}^{2+}$ reabsorption in this tubular segment is enhanced by parathyroid hormone (PTH), thiazide diuretics and alkalemia [3]. 
Figure 1. Calcium reabsorption and calcium-sensing receptor in the nephron. (A) Proximal tubule: $50 \%-60 \%$ of filtered $\mathrm{Ca}^{2+}$ is reabsorbed paracellularly. Luminal calcium-sensing receptor (CSR) activation counteracts parathyroid hormone (PTH)-mediated $\mathrm{P}_{\mathrm{i}}$ excretion, thereby promoting $\mathrm{P}_{\mathrm{i}}$ conservation [11]. (B) Thick ascending limb: $30 \%-35 \%$ of filtered $\mathrm{Ca}^{2+}$ is reabsorbed paracellularly. Basolateral CSR inhibits potassium excretion via renal outer medullary potassium channel (ROMK), diminishing $\mathrm{Ca}^{2+}$ (as well as magnesium) reabsorption. Diminished potassium exit also reduces $\mathrm{NaCl}$ reabsorption via $\mathrm{NKCl}_{2}$, analogous to the effect of loop diuretics [12]. (C) Distal convoluted tubule: $10 \%$ of filtered $\mathrm{Ca}^{2+}$ is reabsorbed transcellularly. Basolateral CSR inhibits plasma membrane calcium ATPase (PMCA), thereby inhibiting transcellular $\mathrm{Ca}^{2+}$ reabsorption [10]. (D) Collecting duct: in the principle cells, activation of CSR inhibits retention of aquaporin-2 in the luminal-surface of the plasma membrane, thereby inhibiting antidiuretic hormone-mediated water conservation, causing renal water wasting $[13,14]$. In the intercalated cells, CSR promotes the activity of proton pump $\left(\mathrm{H}^{+}\right.$-ATPase), enhancing urine acidification, thereby minimizing the risk of $\mathrm{Ca}^{2+} \times \mathrm{P}_{\mathrm{i}}$ supersaturation [15].

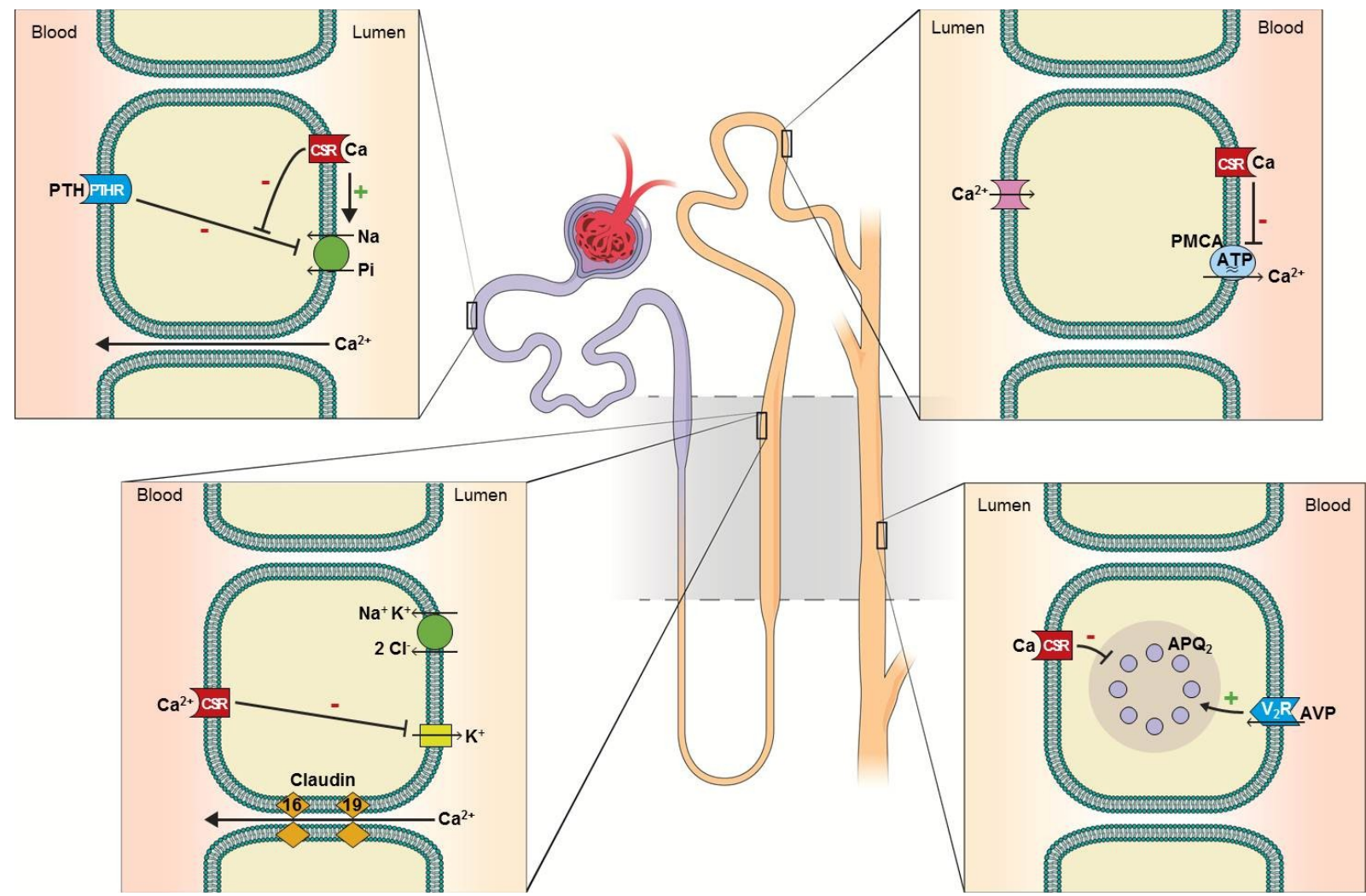

Aging is well-known to be associated with a progressive decline in glomerular filtration rate (GFR). By age $75,30 \%$ of the glomeruli are obsolete, due to sclerosis [16], and the glomerular clearance (of inulin) drops from 122.8 to $65.3 \mathrm{~mL} / \mathrm{min} / 1.73 \mathrm{~m}^{2}$ between the ages of 20-29 and $\geq 80$ [17]. Moreover, tubular excretory capacity, independent of GFR, is reduced by nearly a half (54.6 and $30.8 \mathrm{mg} / \mathrm{min}$ ). Thus, age-related decline in kidney function can substantially diminish kidney reserve. In parallel with aging, the prevalence of CKD has also been steadily rising (CKD definition: Table 1). In the United States, CKD prevalence in those $\geq 20$ years of age has increased from $14.5 \%$ in 
1988-1994 to $16.8 \%$ in 1999-2004, affecting approximately one in six adults [18]. A vast majority of CKD is caused by chronic diabetes and hypertension.

Box 1. Klotho.

- Loss-of-function mutation in Klotho causes premature aging phenotype [19], which led to the initial discovery of the gene and appropriate naming of the gene: Klotho, the Goddess of life.

- Klotho encodes a single-pass transmembrane protein, also termed Klotho, that is expressed primarily in kidney and parathyroid gland [20].

- Klotho couples with FGF23 receptor to form a high-affinity receptor complex for FGF23 and mediates FGF23-induced phosphaturia [21].

- Klotho promotes $\mathrm{Ca}^{2+}$ conservation through stimulating TRPV-5 in the distal convoluted tubule [22].

- Extracellular domain of Klotho can be enzymatically cleaved and shed into the extracellular space, becoming a secreted form of Klotho.

- The secreted form of Klotho exerts pleiotropic activities, including suppression of growth factor signaling [23], oxidative stress [24], inflammation [25] and fibrosis [26].

- Klotho is regarded as an anti-aging molecule [23].

Table 1. The Kidney Disease Outcomes Quality Initiative (KDOQI) - (2002) definition of CKD. GFR, glomerular filtration rate.

- * Stage 1: Kidney damage with GFR greater than $90 \mathrm{~mL} / \mathrm{min} / 1.73 \mathrm{~m}^{2}$.

- * Stage 2: Mild reduction in GFR, $60-89 \mathrm{~mL} / \mathrm{min} / 1.73 \mathrm{~m}^{2}$.

- Stage 3: Moderate reduction in GFR, 30-59 mL/min/1.73 $\mathrm{m}^{2}$.

- Stage 4: Severe reduction in GFR, $15-29 \mathrm{~mL} / \mathrm{min} / 1.73 \mathrm{~m}^{2}$.

- Stage 5: Kidney failure, GFR less than $15 \mathrm{~mL} / \mathrm{min} / 1.73 \mathrm{~m}^{2}$ or dialysis.

* Note: Stage 1 and 2 CKD are not diagnosed based on GFR. There should be other markers of kidney damage, including abnormalities in urine studies, including active urine sediment or proteinuria or abnormalities on kidney imaging studies.

Both aging and $\mathrm{CKD}$ can cause alterations in $\mathrm{Ca}^{2+}$ homeostasis. Age-related decline in kidney function can reduce renal expression of Klotho, leading to diminished vitamin $\mathrm{D}$ activation through fibroblast growth factor-23 (FGF23) signaling and impairment of renal tubular $\mathrm{Ca}^{2+}$ reabsorption [22]. CKD, in addition to aging, can cause a further steep drop in Klotho [27], elevation in FGF23 [28] and more impairment of renal $\mathrm{Ca}^{2+}$ conservation [22,29]. A strong correlation of CKD severity with the magnitude of alterations in FGF23, active vitamin D, PTH, Klotho and bone mineral metabolism has been demonstrated in a number of studies [27,28,30]. Moreover, CKD patients exhibit less regulated intestinal $\mathrm{Ca}^{2+}$ absorption. Spiegel et al. compared differences in $\mathrm{Ca}^{2+}$ balance between healthy individuals and late CKD patients (estimated GFR [eGFR]: 20-33 mL/min/1.73 $\mathrm{m}^{2}$ ) on daily intakes of $800 \mathrm{mg}$ vs. $2000 \mathrm{mg}$ elemental $\mathrm{Ca}^{2+}$ for nine days [31]. Compared to normal individuals, CKD patients demonstrated greater non-regulated intestinal $\mathrm{Ca}^{2+}$ absorption. Low $\mathrm{Ca}^{2+}$ intake $(800 \mathrm{mg})$ in CKD patients resulted in a negative net $\mathrm{Ca}^{2+}$ balance, while high $\mathrm{Ca}^{2+}$ intake $(2000 \mathrm{mg})$ resulted in a positive net $\mathrm{Ca}^{2+}$ balance. These findings indicate that $\mathrm{CKD}$ confers a high-risk of $\mathrm{Ca}^{2+}$ imbalance associated with dietary $\mathrm{Ca}^{2+}$ intake. 
Age-related alterations in $\mathrm{Ca}^{2+}$ homeostasis, with or without $\mathrm{CKD}$, can lead to serious adverse outcomes. Foley et al., showed significant associations between circulating $\mathrm{Ca}^{2+}$, phosphate $\left(\mathrm{P}_{\mathrm{i}}\right)$ and calcium-phosphate $\left(\mathrm{Ca}^{2+} \times \mathrm{P}_{\mathrm{i}}\right)$ product with age, female sex and low eGFR (among others) in 15,732 U.S. community-dwelling individuals (mean age: 54.2 years; mean eGFR: $93.1 \mathrm{~mL} / \mathrm{min} / 1.73 \mathrm{~m}^{2}$ ) followed prospectively over 12.6 years. Notably, after correcting for age and eGFR differences, elevated $\mathrm{Ca}^{2+}$ concentration was associated with higher risk of stroke and elevated $\mathrm{Ca}^{2+} \times \mathrm{P}_{\mathrm{i}}$ product associated with higher risk of both stroke and death [32]. A meta-analysis of randomized, placebo-controlled trials found $\mathrm{Ca}^{2+}$ supplementation, with or without vitamin $\mathrm{D}$, to be positively associated with cardiovascular events [33]. More recently, a prospective population-based study involving 388,229 individuals in the U.S. for a mean follow-up of 12 years also showed a clear association between $\mathrm{Ca}^{2+}$ supplementation and cardiovascular disease and mortality; the association, however, was significant only in men, not in women [34]. In men, there was a U-shaped relation between $\mathrm{Ca}^{2+}$ intake and cardiovascular risk. It was postulated that in women, the results might have been obscured, because of a much younger age in initiation of $\mathrm{Ca}^{2+}$ supplementation. The abrupt increase in serum $\mathrm{Ca}^{2+}$ in men, due to late $\mathrm{Ca}^{2+}$ initiation, can potentially contribute to the adverse outcomes [35]. Consistently, another recent prospective longitudinal study from Europe involving 61,433 women (Swedish mammography cohort) with a median follow-up of 19 years showed significant increase in cardiovascular and all-cause mortality in patients with a high dietary and supplemental $\mathrm{Ca}^{2+}$ intake ( $\geq 1400 \mathrm{mg} /$ day) [36]. Interestingly, a non-significant $\mathrm{U}$-shaped trend between $\mathrm{Ca}^{2+}$ intake and cardiovascular risk was also observed. Overall, it seems apparent that high $\mathrm{Ca}^{2+}$ intake can adversely impact cardiovascular disease and mortality.

Chronic hypocalcemia or net negative $\mathrm{Ca}^{2+}$ balance, conversely, is known to be associated with osteopenia and osteoporosis, resulting in fractures, morbidity and mortality [37,38]. Studies have shown approximately $18 \%$ of hospitalized patients [39] and $85 \%$ of intensive care unit patients [40] are hypocalcemic. Kolb et al. studied 94 post-menopausal females with a mean age of 74.9 years who presented with distal radial fractures requiring surgical repair [41]. At presentation, 83.5\% were vitamin D-deficient (mean \pm SEM: $19.6 \pm 21.9 \mathrm{ng} / \mathrm{mL}$; optimal levels $>30 \mathrm{ng} / \mathrm{mL}$ ) and $21.3 \%$ hypocalcemic $(8.92 \pm 1.4 \mathrm{mg} / \mathrm{dL}$; normal range: $8.9-10.1 \mathrm{mg} / \mathrm{dL}) . \mathrm{Ca}^{2+}$ and vitamin $\mathrm{D}$ supplementation post-surgery for six weeks improved serum vitamin $\mathrm{D}, \mathrm{Ca}^{2+}$ and fracture site callus formation. The supplementation also normalized PTH levels in those with PTH elevation. While osteopenia and osteoporosis are much more common in elderly women, primarily related to estrogen reduction, elderly males are not spared. In a prospective study of $178 \mathrm{men}$, age was associated with a decrease in intestinal $\mathrm{Ca}^{2+}$ absorption, related to the co-existing vitamin D reduction [42]. Notably, the magnitude of hypocalcemia in these studies was relatively small, as observed in prior studies [43,44]; however, $\mathrm{Ca}^{2+}$ concentration is maintained at the cost of hyper- or hypo-activations in multiple regulatory elements (serum $\mathrm{P}_{\mathrm{i}}$, vitamin D, PTH, FGF23/Klotho and CSR-mediated signaling) and active bone destruction. All of the elements are heavily influenced, directly or indirectly, by CKD. Below, we review the $\mathrm{Ca}^{2+}$ regulatory mechanisms and bone mineral metabolism with special emphasis on pathophysiology relating to aging and CKD. 


\section{Phosphate}

Western diet contains $0.8-1.5 \mathrm{~g}$ of $\mathrm{P}_{\mathrm{i}}$ daily. Seventy to $90 \%$ of dietary $\mathrm{P}_{\mathrm{i}}$ is absorbed, a process enhanced by active vitamin D. $P_{i}$ is predominantly distributed in bone and cells with $<1 \%$ in the circulation. When in balance, net $\mathrm{P}_{i}$ mobilization from bone is negligible; therefore, absorbed dietary $\mathrm{P}_{\mathrm{i}}$ is excreted predominantly by the kidneys. Following glomerular filtration, a large proportion of $\mathrm{P}_{\mathrm{i}}$ is reabsorbed in the proximal tubules. The reabsorption is regulated by dietary $\mathrm{P}_{\mathrm{i}}, \mathrm{PTH}, \mathrm{FGF} 23$ and chronic metabolic acidosis, all promoting $\mathrm{P}_{\mathrm{i}}$ excretion [3].

Age-related decline in GFR and tubular excretory capacity reduces renal reserve, predisposing to $\mathrm{P}_{\mathrm{i}}$ retention. Consistently, elderly patients are found to be at a higher risk for acute $\mathrm{P}_{\mathrm{i}}$ nephropathy following ingestion of $\mathrm{P}_{\mathrm{i}}$-containing purgatives [45]. CKD further reduces $\mathrm{P}_{\mathrm{i}}$ excretion capacity, causing $\mathrm{P}_{\mathrm{i}}$ retention. FGF23 elevation in early CKD may mitigate $\mathrm{P}_{\mathrm{i}}$ retention by inhibiting tubular $\mathrm{P}_{\mathrm{i}}$ reabsorption [46]. In late $\mathrm{CKD}\left(\mathrm{eGFR}<40 \mathrm{~mL} / \mathrm{min} / 1.73 \mathrm{~m}^{2}\right.$ ), such compensation becomes insufficient and hyperphosphatemia ensues [43,44,47]. Hyperphosphatemia inhibits $1 \alpha$-hydroxylation of vitamin D and stimulates FGF23 and PTH production and parathyroid hyperplasia. Hyperphosphatemia also reduces $\mathrm{Ca}^{2+}$ in the circulation; the resulting hypocalcemia further stimulates PTH synthesis and secretion. All of these factors contribute to the development of secondary hyperparathyroidism and MBD.

Beyond bone mineral regulation, $\mathrm{P}_{\mathrm{i}}$ is an emerging key regulator of aging and vascular calcification. Hyperphosphatemia stimulates osteogenic transformation and apoptosis of vascular smooth muscle cells, causing expression of genes promoting matrix mineralization and $\mathrm{Ca}^{2+}$ deposition [48-50]. Hyperphosphatemia clinically is linked to accelerated vascular calcification and mortality [51-53]. Dietary $\mathrm{P}_{\mathrm{i}}$ restriction in a mouse model ameliorates the premature-aging phenotype [54].

\section{Vitamin D}

The major source of vitamin $\mathrm{D}$, without supplementation, is from skin. Cholecalciferol (vitamin $\left.\mathrm{D}_{3}\right)$ is produced through conversion of 7-dehydrocholesterol stimulated by ultraviolet radiation in sunlight. A casual 10-20 min of noontime-sun exposure generates an adequate daily requirement of vitamin D [55]. Insufficient sun exposure can cause vitamin D deficiency. Day-to-day western food is a poor source of vitamin D. Consequently, dairy products, such as milk, have been fortified with cholecalciferol or ergocalciferol (vitamin $D_{2}$ ). Both vitamins $D_{3}$ and $D_{2}$ are converted to 25-hydroxyvitamin D (25[OH]D) via hepatic P-450 enzymes [56]. In the circulation, 25(OH)D binds to vitamin D-binding protein and is further $1 \alpha$-hydroxylated in the kidney to the highly active 1,25-dihydroxyvitamin D $\left(1,25[\mathrm{OH}]_{2} \mathrm{D}\right.$, calcitriol); $\sim 100$-fold efficacy of that in $25(\mathrm{OH}) \mathrm{D} .25(\mathrm{OH}) \mathrm{D}$ and $1,25(\mathrm{OH})_{2} \mathrm{D}$ can be converted to inactive $24,25(\mathrm{OH})_{2} \mathrm{D}$ in both the liver and kidneys [57]. The conversion to active vitamin $\mathrm{D}\left(1,25[\mathrm{OH}]_{2} \mathrm{D}\right)$ is highly regulated, promoted by PTH and inhibited by FGF23 and hyperphosphatemia.

At the cellular level, active vitamin D binds to vitamin D receptor (VDR), dimerizes with the retinoid x-receptor and activates downstream transcriptions [58]. Through this mechanism, vitamin D can be involved in a variety of genomic regulations, including the regulation of hematopoietic cells, muscle function, immunomodulatory function, inflammation and fibrosis, beyond vitamin D's classic 
roles in mineral metabolism, i.e., promoting intestinal $\mathrm{Ca}^{2+}$ and $\mathrm{P}_{\mathrm{i}}$ absorption and facilitating PTH-mediated bone resorption [59]. The pleiotropic effects of vitamin D have been linked to multiple health benefits, e.g., lowering blood pressure via inhibition of the renin-angiotensin-aldosterone system [60-63] and lowering the risk of diabetes [64,65], colorectal and breast cancer [66] and infection in immunodeficient patients [67]. Vitamin D deficiency is also found to be associated with poor cognitive function and risk for Alzheimer disease [68], possibly relating to vitamin D's role in phagocytosing soluble amyloid- $\beta$ [69]. The survival advantage in individuals with an adequate vitamin D store has been demonstrated in several epidemiological studies [37,70-72].

With growing recognition of salutatory effects of vitamin $\mathrm{D}$, the threshold for optimal vitamin $\mathrm{D}$ status has been raised to a serum $25(\mathrm{OH}) \mathrm{D}$ level of $>30 \mathrm{ng} / \mathrm{mL}(75 \mathrm{nmol} / \mathrm{L})$ [73-75]. 25(OH)D levels are chosen as a surrogate for vitamin D status, because of its stability and ease of assaying [76]. Per this definition, over half of the U.S. and European community-dwelling populations are classified as vitamin D-deficient and 40\%-50\% have levels $<20 \mathrm{ng} / \mathrm{mL}(50 \mathrm{nmol} / \mathrm{L})$ [77,78]. Elderly CKD patients are at a particular risk for vitamin D deficiency. Age reduces skin production [79] and intestinal absorption of vitamin D [80]. Age-related GFR decline reduces $1 \alpha$-hydroxylation and attendant vitamin $\mathrm{D}$ activation. CKD-associated $\mathrm{P}_{\mathrm{i}}$ retention and FGF23 elevation inhibit $1 \alpha$-hydroxylase activity, further impairing vitamin D activation [23]. Additionally, proteinuria, often associated with CKD, can increase urine loss of protein-bound 25(OH)D [81].

Similar to the observations in the general population, vitamin D deficiency in CKD is associated with increased mortality [82]. In the elderly ( $\geq 65$ years old), intake of vitamin D ( $\geq 800 \mathrm{IU}$ ) with $\mathrm{Ca}^{2+}$ reduces fracture risk by $\sim 14 \%-30 \%$ [83]. Moreover, vitamin D or analogue (paricalcitol) supplementation reduces albuminuria, systemic blood pressure [84] and vascular calcification [85] and improves patient survival with [86] or without [87-89] $\mathrm{Ca}^{2+}$ cosupplementation. The potential mechanisms of vitamin D-associated survival advantage are an area of active research. A recent study shows that vitamin $\mathrm{D}$ or paricalcitol administration, equivalent to the dose used in CKD patients, in mouse (50\% and 75\%) renal ablation models is associated with an elevated serum and urinary Klotho and reduction in the magnitude of arterial calcification compared with untreated controls [90]. Given the known anti-aging effect of Klotho, it is tempting to speculate that the benefit of vitamin D in CKD might be related to the enhanced Klotho signal. Although there is much more to be learned about the beneficial effects of vitamin D supplementation, the study begins to draw a connection between vitamin D, vascular calcification and aging. It provides support for current practice guidelines, advocating vitamin $\mathrm{D}$ repletion for CKD patients.

\section{Parathyroid Hormone}

Intact PTH is an 84-amino acid peptide produced by the parathyroid glands. It has a half-life of $\sim 10 \mathrm{~min}$, and the N-terminal portion is biologically active. PTH is metabolized in the liver, and the resulting inactive C-terminal portion is excreted by the kidneys [91,92]. PTH production is stimulated by hypocalcemia, sensed through CSR [93,94], and inhibited by vitamin D, sensed through VDR [95]. The effector organs of PTH are bone and the kidneys. In bone, PTH receptor is expressed in both osteoblasts and osteoclasts, where, in concert with active vitamin D, it accelerates bone turnover. PTH 
also increases FGF23 gene expression (Figure 2) [96]. In the kidneys, PTH stimulates 1 $\alpha$-hydroxylation of vitamin $\mathrm{D}$, reduces proximal tubular $\mathrm{P}_{\mathrm{i}}$ reabsorption and enhances distal tubular $\mathrm{Ca}^{2+}$ reabsorption [97].

Figure 2. Interplay of PTH, FGF23 and active vitamin D: PTH increases bone FGF23 gene expression [96] (Green, Parathyroid Gland $\rightarrow$ Bone) and kidney proximal tubule $1 \alpha$-hydroxylation of 25(OH)D [97] (Green, Parathyroid Gland $\rightarrow$ Kidney). 1,25(OH)D2 (active vitamin D) binds to parathyroid vitamin D receptor (VDR), inhibiting PTH gene transcription [95] (Red, Kidney $\rightarrow$ Parathyroid Gland) and stimulates osteoblast and osteoclast FGF23 production [98] (Green, Kidney $\rightarrow$ Bone). FGF23 increases parathyroid CSR and VDR expression, inhibiting PTH production [99] (Red, Bone $\rightarrow$ Parathyroid Gland). FGF23 also decreases kidney proximal tubule $1 \alpha$-hydroxylation, reducing vitamin $\mathrm{D}$ activation, and increases kidney (and liver) 24-hydroxylation of $25(\mathrm{OH}) \mathrm{D}$, enhancing vitamin D inactivation [100] (Red, Bone $\rightarrow$ Kidney).

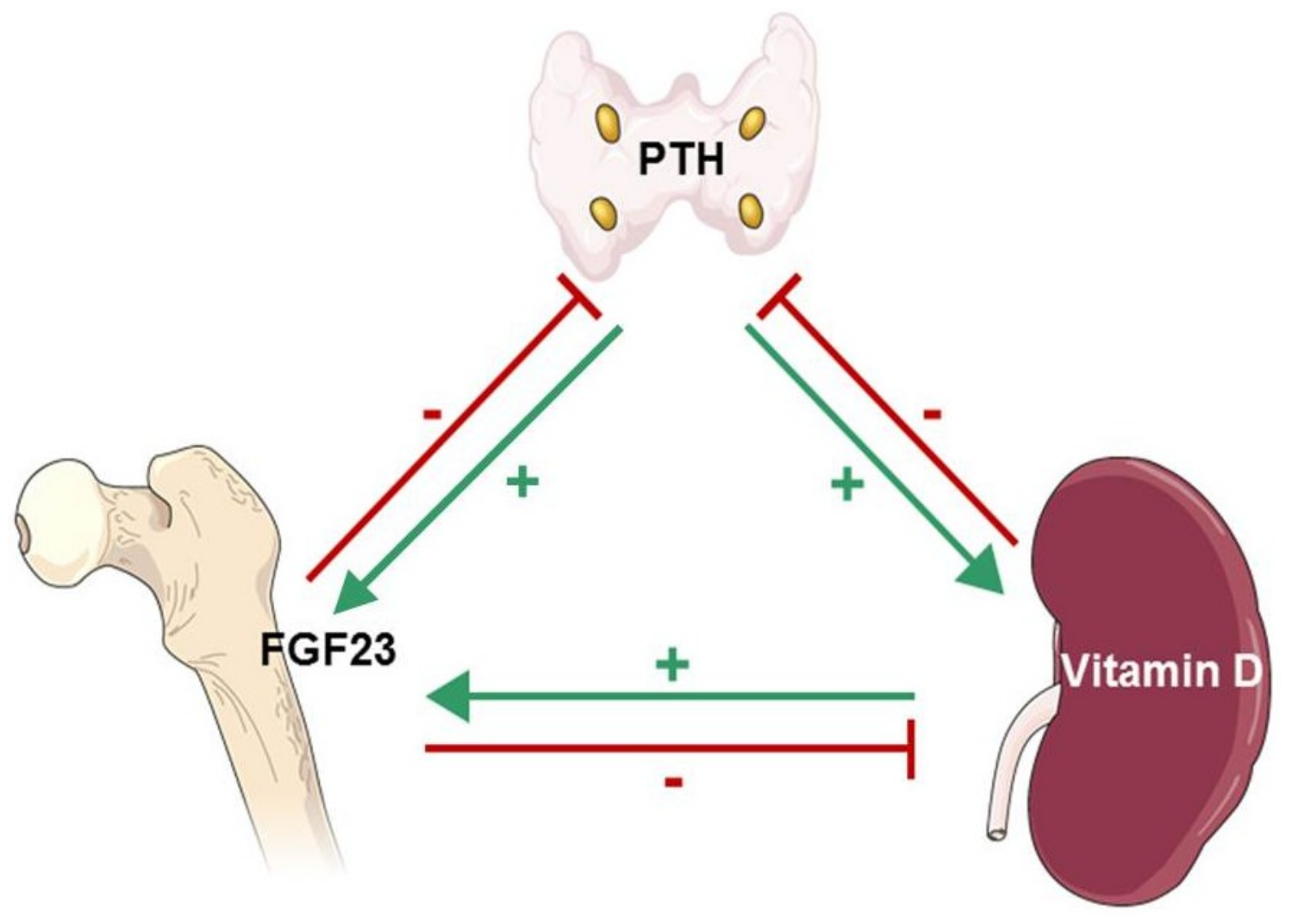

The elderly population has a higher occurrence of primary hyperparathyroidism, due to benign parathyroid adenoma [101]. CKD exerts an important impact on PTH, as the impairment of $\mathrm{P}_{\mathrm{i}}$ excretion and hypocalcemia in CKD stimulates PTH synthesis and secretion, causing secondary hyperparathyroidism. Due to the impairment of $\mathrm{P}_{\mathrm{i}}$ excretion and a degree of bone resistance to $\mathrm{PTH}$ in CKD, the reference range of serum PTH for CKD patients is raised to $150-300 \mathrm{pg} / \mathrm{mL}$ from $<65 \mathrm{pg} / \mathrm{mL}$ in the general population, as a higher level of PTH is necessary to maintain adequate bone turnover in CKD. A PTH level $>300 \mathrm{pg} / \mathrm{mL}$ is an indication for active treatment [102]. Levels $<150 \mathrm{pg} / \mathrm{mL}$ are considered a sign of adynamic bone disease, and therapies that may suppress PTH (e.g., calcium, vitamin D and its analogues) should be avoided [103,104]. Although secondary hyperparathyroidism is evident in the majority of CKD patients and is associated with the genesis of 
MBD and MBD-related complications, the direct relation between PTH and cardiovascular complications or cardiovascular disease-related mortality in CKD is unclear and needs to be further studied.

\section{Fibroblast Growth Factor-23}

FGF23, a member of the phosphatonin family of proteins, is a 251-amino acid peptide [105]. It is produced by osteoclasts and osteoblasts and plays a major role in $\mathrm{P}_{\mathrm{i}}$ and, indirectly, $\mathrm{Ca}^{2+}$ homeostasis $[100,106,107]$. The production of FGF23 is stimulated by active vitamin D and likely by positive net $\mathrm{P}_{\mathrm{i}}$ balance [98]. FGF23 binds to its receptor complex (Klotho-FGFR-1) and induces phosphaturia by suppressing luminal-surface expression of sodium- $\mathrm{P}_{\mathrm{i}}$ co-transporters $2 \mathrm{~A}$ and $2 \mathrm{C}$ in the renal proximal tubules [100]. It also suppresses the $1 \alpha$-hydroxylation of vitamin $\mathrm{D}$ by inhibiting 1 $\alpha$-hydroxylase (CYP27B1) activity and by increasing 24-hydroxylase activity, which increases the production of inactive $24,25(\mathrm{OH})_{2} \mathrm{D}$ (Figure 2). Thus, FGF23 reduces $\mathrm{P}_{\mathrm{i}}$ and $\mathrm{Ca}^{2+}$. Additionally, FGF23 increases gene expression and protein production of CSR and VDR, reducing parathyroid cell proliferation, attenuating parathyroid function [99]. In vitro, high- $\mathrm{Ca}^{2+}$ concentrations have been shown to increase both parathyroid Klotho and FGF receptor expression, suggesting that hypercalcemia may promote the effect of FGF23 on the parathyroid glands [108]. FGF23 is inactivated by an endopeptidase. Mutations in the endopeptidase cause hypophosphatemic rickets associated with renal $\mathrm{P}_{\mathrm{i}}$ wasting and osteomalacia [109].

Mesenchymal tumors are seen in elderly and associated with FGF23 over-production and urine $\mathrm{P}_{\mathrm{i}}$ wasting, hypophosphatemia, $1,25(\mathrm{OH})_{2} \mathrm{D}$ deficiency and osteomalacia [110,111]. Rare forms of FGF23 gain-of-function [112] and loss-of-function [113] mutations can cause familial forms of hyper- or hypophosphatemia, vitamin D alterations and soft-tissue injury. A much more common cause of FGF23 elevation, however, is CKD. Even in patients with a mild degree of CKD, FGF23 can be elevated. Westerberg et al. reported the observation of transient FGF23 elevation in healthy individuals after kidney donation. The elevation seems to be associated with transient reduction in eGFR and active vitamin $D$ with net positive $P_{i}$ balance. Once the remaining kidney improves its clearance by compensation, FGF23 level returns to normal, along with normalization of $\mathrm{P}_{\mathrm{i}}$ balance and active vitamin D [99]. Even in early stage CKD, FGF23 elevation is persistent and accompanied by a decline in Klotho, rendering resistance to FGF23-mediated effects. FGF23 elevation in CKD is associated with several adverse outcomes, including: (1) greater risk of end stage renal disease (ESRD) (if eGFR > $30 \mathrm{~mL} / \mathrm{min} / 1.73 \mathrm{~m}^{2}$ ) [30]; (2) faster progression to refractory secondary hyperparathyroidism [108]; (3) left ventricular hypertrophy [114,115] and (4) higher mortality rate in dialysis patients [116,117]. Studies using rat CKD (nephritic and 5/6 nephrectomy) models showed that monoclonal-FGF23 antibody injection was associated with a reversal of secondary hyperparathyroidism, increase in serum vitamin $\mathrm{D}$ and $\mathrm{Ca}^{2+}$ and normalization of bone markers $[118,119]$. However, kidney function was unchanged, and there was an FGF23-antibody dose-dependent increase in serum $\mathrm{P}_{\mathrm{i}}$ and aortic calcification [119]. In aggregate, FGF23 inhibition in this model ameliorated MBD, but had no effect on kidney function, vascular calcification and mortality. It would be informative to further investigate whether dietary $P_{i}$ restriction, in addition to FGF23 ablation, alters the final outcome. 


\section{Calcium Sensing Receptor}

CSR, a G-protein coupled receptor activated by $\mathrm{Ca}^{2+}$, is abundantly expressed in the parathyroid glands, bone and kidneys [93]. In the parathyroid glands, CSR expression is upregulated by vitamin D [120], and CSR activation inhibits synthesis and secretion of PTH [93]. In bone, CSR inhibits osteoclast activity and stimulates osteoblast activity, causing a diminished release of $\mathrm{Ca}^{2+}[121]$. In the kidney, CSR is expressed in the luminal aspect of the proximal tubule and collecting duct and the basolateral aspect of the thick ascending limb and distal convoluted tubule (Figure 1) [94]. CSR activation inhibits renal $\mathrm{Ca}^{2+}$ reabsorption, acidifies urine and simultaneously causes salt and water wasting. Gain-of-function [122,123] and loss-of-function [124,125] mutations in CSR cause a spectrum of defects in $\mathrm{Ca}^{2+}$ homeostasis, parathyroid function and fluid regulation.

Aging and CKD can have profound effects on both extrarenal and renal CSR by altering $\mathrm{Ca}^{2+}$ homeostasis. In the parathyroid glands, hypocalcemia seen in elderly CKD patients diminishes CSR signaling and releases CSR-mediated PTH inhibition, thereby enhancing PTH synthesis and secretion and promoting parathyroid hyperplasia. In bone, diminished CSR signaling can cause an accelerated bone resorption and attenuated bone formation and chondrogenesis [126]. In the kidney, a diminished CSR signal favors tubular $\mathrm{Ca}^{2+} \times \mathrm{P}_{\mathrm{i}}$ precipitation and fluid retention.

\section{Mineral and Bone Disorder}

MBD in elderly CKD patients is common and is etiologically related to altered balance in blood $\mathrm{Ca}^{2+}$ and $\mathrm{P}_{\mathrm{i}}$. It is a systemic disorder characterized by one or more of the following [127]:

1. Laboratory abnormalities (i.e., serum $\mathrm{Ca}^{2+}$ and $\mathrm{P}_{\mathrm{i}}, \mathrm{PTH}$ and/or vitamin $\mathrm{D}$ ).

2. Abnormalities in bone turnover, mineralization or volume.

3. Vascular or other soft tissue calcification.

Bone abnormalities in CKD-MBD range from the more common high-turnover osteitis fibrosa to low-turnover adynamic bone disease [128]. Mixed bone disease displays features of both high- and low-turnover. PTH, through its major downstream regulators osteoprotegerin (OPG) and receptor activator of NFKB-ligand (RANK-L), plays a major role in accelerating bone turnover. When RANK-L engages RANK, it activates osteoclasts, causing bone resorption. Osteoprotegerin (OPG) is a decoy for RANK-L and when engaged inactivates osteoclasts, decreasing bone resorption [129]. PTH simultaneously stimulates RANK-L expression and inhibits OPG production [130,131]. Patients with diabetes [132] and those on peritoneal dialysis [133] are predisposed to adynamic bone disease, associated with reduced PTH $(<150 \mathrm{pg} / \mathrm{mL})$, bone cellular activity and turnover [134]. These patients are at a high risk for hypercalcemia, due to a lack of bone buffering of the circulating $\mathrm{Ca}^{2+}$. Both the high- and low-turnover varieties of CKD-MBD are associated with increased risk of fracture, bone symptoms (e.g., bone pain), $\mathrm{Ca}^{2+} \times \mathrm{P}_{\mathrm{i}}$ elevation, soft tissue and vasculature calcification and overall mortality [135]. Osteomalacia, featuring large amounts of osteoid material with deficient mineralization, occurs much less frequently in elderly CKD patients [136].

Duel-energy X-ray absorptiometry (DEXA) is routinely used clinically for assessing bone mineral density; its utility in CKD is limited as it fails to provide information on bone quality and architecture [137]. Biopsy of trabecular bone for histomorphometric analysis is the gold standard for 
diagnosis and ongoing evaluation of CKD-MBD [138]. In patients with high-turnover bone disease, there is trabecular thickening, increased resorptive activity, active mineralization and a background of marrow fibrosis. Marrow fibrosis can contribute to anemia and erythropoietin resistance. Excessive resorptive activity can cause release of minerals from the bone, promoting extraskeletal $\mathrm{Ca}^{2+} \times \mathrm{P}_{\mathrm{i}}$ precipitation. In severe high-turnover MBD, normal lamella structure turns to a woven structure with haphazard organization [139]. At the other extreme, adynamic bone disease, bone tissue can show normal or thickened trabeculae with diminished or absent cellular activity. Tetracycline-labeling can be used to assess the pace of bone turnover [140].

Extraskeletal calcification, including vascular calcification, is an integral part of CKD-MBD. Both aging and CKD are intimately associated with the development and progression of soft tissue calcification. Incidence and progression of vascular calcification in the elderly is inversely related to bone mass [141,142]. Moreover, bone mineral loss and vascular calcification are prominent risk factors of fracture and all-cause mortality [143]. CKD in the elderly is a profound risk factor for the development of vascular calcification and vascular aging. Vascular calcification is evident in up to 94\% of pre-dialysis CKD patients $[144,145]$ and consistent with CKD patients dying from early onset of age-associated diseases, e.g., cardiovascular disease [146] and diabetes mellitus [147]. CKD is recognized as a model of premature aging [148].

Multiple mechanisms have been implicated in the genesis of vascular calcification and aging in CKD. In addition to hyperphosphatemia-mediated osteogenic transformation of soft tissue, uremic milieu can provoke phenotypic transition of vascular smooth muscle cells from the contractile phenotype to osteoblast-like phenotype [49]. This process is promoted by multiple factors, including osteoblastic morphogens (i.e., the bone morphogenetic protein-2 and -4), core-binding factor $\alpha 1$ (also termed RUNX-2) and bone-related proteins, such as alkaline phosphatase and osteocalcin [149]. A recent study also shows that Klotho deficiency can trigger vascular calcification [150].

Vascular calcification, a strong risk factor for mortality, is likely a dynamic process and can potentially be modified. Sigrist et al. investigated the progression of vascular calcification over a two-year period in a cohort of CKD (60 hemodialysis, 28 peritoneal dialysis and 46 stage 4 CKD) patients [151]. There was an increase in the radiological evidence of vascular calcification in the two-year interval. The increase was associated with a widened pulse pressure and elevated pulse-wave velocity. The mortality during the study period was $42 \%$ in hemodialysis, $33 \%$ in peritoneal dialysis and $14 \%$ in stage 4 non-dialysis CKD. Increase in calcification score and $\mathrm{Ca}^{2+}$ intake (from $\mathrm{P}_{\mathrm{i}}$ binders) and reduction in baseline plasma albumin were associated with reduced survival. Intriguingly, one-third of the patients in the three subgroups remained free of vascular calcification, and a small percentage $(4 \%-8 \%)$ of the patients demonstrated regression. These findings suggest a dynamic process of vascular calcification that could potentially be modified, providing rationale for early intervention and aggressive control of calcification risks in CKD.

\section{Recommendations}

Current guidelines from KDOQI (Kidney Disease Outcomes Quality Initiative) are that vitamin D deficiency in patients with CKD should be treated as in the general population [136]. $\mathrm{Ca}^{2+}$ intake in elderly CKD patients should generally be approximately $800-1000 \mathrm{mg}$ daily. Overzealous $\mathrm{Ca}^{2+}$ 
supplementation should be avoided. For CKD patients with evidence of secondary hyperparathyroidism, regular monitoring of serum $\mathrm{Ca}^{2+}, \mathrm{P}_{\mathrm{i}}, \mathrm{PTH}$ and vitamin $\mathrm{D}$ is necessary. For patients with stages 3-4 CKD, serum $\mathrm{Ca}^{2+}$ should be maintained within normal range, 8.9-10.1 mg/dL, $\mathrm{P}_{\mathrm{i}}$ should be within $2.7-4.6 \mathrm{mg} / \mathrm{dL}$ and PTH within $100-200 \mathrm{pg} / \mathrm{mL}$. For patients with stage $5 \mathrm{CKD}, \mathrm{Ca}^{2+}$ should also be kept at normal range, $\mathrm{P}_{\mathrm{i}}$ target should be $<5.5 \mathrm{mg} / \mathrm{dL}$ and $\mathrm{PTH}$ in the range of $150-300 \mathrm{pg} / \mathrm{mL}$. These targets can potentially be achieved with dietary modification and the appropriate use of $\mathrm{P}_{\mathrm{i}}$ binders, vitamin D (i.e., active vitamin D or analogues) and calcimimetics (i.e., cinacalcet) [152], alone or in combination.

Although $\mathrm{P}_{\mathrm{i}}$ binders are routinely used in dialysis patients, for non-dialysis CKD patients, when to initiate them is uncertain. Moreover, whether there is any advantage to using $\mathrm{Ca}^{2+}$-free over $\mathrm{Ca}^{2+}$-containing preparations is unclear. A randomized, double-blind trial by Block et al. compared calcification scores for late CKD patients (eGFR: 20-45 mL/min $/ 1.73 \mathrm{~m}^{2}$ ) on $\mathrm{P}_{\mathrm{i}}$ binders (aggregate of $\mathrm{Ca}^{2+}$-containing and $\mathrm{Ca}^{2+}$-free binders) versus placebo for six months [153]. Despite $\mathrm{P}_{\mathrm{i}}$ reduction, $\mathrm{P}_{\mathrm{i}}$ binders failed to reduce vascular calcification scores. The study was not powered to differentiate calcification scores between $\mathrm{Ca}^{2+}$-containing and $\mathrm{Ca}^{2+}$-free $\mathrm{P}_{\mathrm{i}}$ binders. Chue et al. investigated a cohort of non-diabetic early CKD patients (mean eGFR: $50 \mathrm{~mL} / \mathrm{min} / 1.73 \mathrm{~m}^{2}$ ) randomly assigned to receive $\mathrm{Ca}^{2+}$-free $\mathrm{P}_{\mathrm{i}}$ binder (sevelamer) $(n=55)$ or placebo $(n=54)$ for 40 weeks [154]. Only $56 \%$ of the sevelamer group achieved $>80 \%$ compliance, and these patients were analyzed. They found a reduction in serum FGF23 and urinary $\mathrm{P}_{\mathrm{i}}$ excretion, however there was no reduction in cardiovascular-related outcomes. Further investigations with a better drug preparation to enhance compliance, larger patient cohort and longer study duration can be informative.

Vitamin D analogues (doxercalciferol and paricalcitol) are commonly used for controlling secondary hyperparathyroidism; paricalcitol has a lesser hypercalcemic and hyperphosphatemic effect $[72,155]$. Calcimimetic CSR blocker (cinacalcet) has also been introduced in recent years (FDA-approved in March, 2004) for treating severe (PTH $>600 \mathrm{pg} / \mathrm{mL}$ ) secondary hyperparathyroidism [156]. The EVOLVE (evaluation of cinacalcet HCL therapy to lower cardiovascular events) trial demonstrated efficacy of cinacalcet in PTH reduction in dialysis patients with pre-therapeutic median PTH of $\sim 690 \mathrm{pg} / \mathrm{mL}$. After adjusting for baseline characteristics, cinacalcet was associated with reduced cardiovascular mortality [157]. Without the data adjustments, however, cinacalcet failed to show a survival advantage. The study also revealed intolerance to cinacalcet (primarily hypocalcemia, nausea and vomiting) in nearly a third of the patients. Thus, apart from PTH reduction, the clinical value of cinacalcet in CKD remains uncertain.

\section{Concluding Remarks}

Elderly CKD population is on the rise. $\mathrm{Ca}^{2+}$ homeostasis is altered in the majority of these patients, manifested predominantly as hypocalcemia, hyperphosphatemia, vitamin D deficiency, FGF23 elevation (coupled with Klotho deficiency) and secondary hyperparathyroidism. These defects are deleterious to bone and soft-tissue health, leading to the development of MBD, which is associated with morbid clinical outcomes, including fracture, cardiovascular events and all-cause mortality. Recent studies suggest that vascular calcification in CKD might be prevented and/or ameliorated by correcting the $\mathrm{Ca}^{2+}$ alterations and vitamin $\mathrm{D}$ deficiency and by optimizing $\mathrm{Ca}^{2+} \times \mathrm{P}_{\mathrm{i}}$ product levels. A guideline 
(KDOQI)-driven multi-disciplinary approach involving nephrologists, primary care physicians, physician assistants/extenders, nurses, dietitians and pharmacists for managing elderly CKD patients with $\mathrm{Ca}^{2+}$ dysregulation and MBD can be efficient, effective and is advisable.

\section{Conflict of Interest}

The authors declare no conflict of interest.

\section{References}

1. World Population Prospects: The 2010 Revision, Volume I: Comprehensive Tables; United Nations Department of Economic and Social Affairs Population Division: New York, NY, USA, 2011.

2. Peacock, M. Calcium metabolism in health and disease. Clin. J. Am. Soc. Nephrol. 2010, 5, S23-S30.

3. Koeppen, B.M.; Stanton, B.A. Renal Physiology, 5th ed.; Elsevier: Philadelphia, PA, USA; p. 240.

4. Hebert, S.C. Calcium and salinity sensing by the thick ascending limb: A journey from mammals to fish and back again. Kidney Int. Suppl. 2004, 91, S28-S33.

5. Hebert, S.C.; Brown, E.M.; Harris, H.W. Role of the $\mathrm{Ca}(2+)$-sensing receptor in divalent mineral ion homeostasis. J. Exp. Biol. 1997, 200, 295-302.

6. Hou, J.; Rajagopal, M.; Yu, A.S. Claudins and the Kidney. Annu. Rev. Physiol. 2013, 75, 479-501.

7. Vennekens, R.; Hoenderop, J.G.; Prenen, J.; Stuiver, M.; Willems, P.H.; Droogmans, G.; Nilius, B.; Bindels, R.J. Permeation and gating properties of the novel epithelial $\mathrm{Ca}(2+)$ channel. J. Biol. Chem. 2000, 275, 3963-3969.

8. Chang, Q.; Hoefs, S.; van der Kemp, A.W.; Topala, C.N.; Bindels, R.J.; Hoenderop, J.G. The beta-glucuronidase klotho hydrolyzes and activates the TRPV5 channel. Science 2005, 310, 490-493.

9. Cha, S.K.; Ortega, B.; Kurosu, H.; Rosenblatt, K.P.; Kuro-o, M.; Huang, C.L. Removal of sialic acid involving Klotho causes cell-surface retention of TRPV5 channel via binding to galectin-1. Proc. Natl. Acad. Sci. USA 2008, 105, 9805-9810.

10. Blankenship, K.A.; Williams, J.J.; Lawrence, M.S.; McLeish, K.R.; Dean, W.L.; Arthur, J.M. The calcium-sensing receptor regulates calcium absorption in MDCK cells by inhibition of PMCA. Am. J. Physiol. Renal Physiol. 2001, 280, F815-F822.

11. Ba, J.; Brown, D.; Friedman, P.A. Calcium-sensing receptor regulation of PTH-inhibitable proximal tubule phosphate transport. Am. J. Physiol. Renal Physiol. 2003, 285, F1233-F1243.

12. Hebert, S.C. Bartter syndrome. Curr. Opin. Nephrol. Hypertens. 2003, 12, 527-532.

13. Earm, J.H.; Christensen, B.M.; Frøkiaer, J.; Marples, D.; Han, J.S.; Knepper, M.A.; Nielsen, S. Decreased aquaporin-2 expression and apical plasma membrane delivery in kidney collecting ducts of polyuric hypercalcemic rats. J. Am. Soc. Nephrol. 1998, 9, 2181-2193.

14. Procino, G.; Mastrofrancesco, L.; Tamma, G.; Lasorsa, D.R.; Ranieri, M.; Stringini, G.; Emma, F.; Svelto, M.; Valenti, G. Calcium-sensing receptor and aquaporin 2 interplay in hypercalciuria-associated renal concentrating defect in humans. An in vivo and in vitro study. PLoS One 2012, 7, e33145. 
15. Renkema, K.Y.; Velic, A.; Dijkman, H.B.; Verkaart, S.; van der Kemp, A.W.; Nowik, M.; Timmermans, K.; Doucet, A.; Wagner, C.A.; Bindels, R.J.; Hoenderop, J.G. The calcium-sensing receptor promotes urinary acidification to prevent nephrolithiasis. J. Am. Soc. Nephrol. 2009, 20, 1705-1713.

16. Nyengaard, J.R.; Bendtsen, T.F. Glomerular number and size in relation to age, kidney weight, and body surface in normal man. Anat. Rec. 1992, 232, 194-201.

17. Davies, D.F.; Shock, N.W. Age changes in glomerular filtration rate, effective renal plasma flow, and tubular excretory capacity in adult males. J. Clin. Invest. 1950, 29, 496-507.

18. CDC. Prevalence of chronic kidney disease and associated risk factors-United States, 1999-2004. MMWR Morb. Mortal. Wkly. Rep. 2007, 56, 161-165.

19. Kuro-o, M.; Matsumura, Y.; Aizawa, H.; Kawaguchi, H.; Suga, T.; Utsugi, T.; Ohyama, Y.; Kurabayashi, M.; Kaname, T.; Kume, E.; et al. Mutation of the mouse klotho gene leads to a syndrome resembling ageing. Nature 1997, 390, 45-51.

20. Shiraki-Iida, T.; Aizawa, H.; Matsumura, Y.; Sekine, S.; Iida, A.; Anazawa, H.; Nagai, R.; Kuro-o, M.; Nabeshima, Y. Structure of the mouse klotho gene and its two transcripts encoding membrane and secreted protein. FEBS Lett. 1998, 424, 6-10.

21. Kurosu, H.; Ogawa, Y.; Miyoshi, M.; Yamamoto, M.; Nandi, A.; Rosenblatt, K.P.; Baum, M.G.; Schiavi, S.; Hu, M.C.; Moe, O.W.; Kuro-o, M. Regulation of fibroblast growth factor-23 signaling by klotho. J. Biol. Chem. 2006, 281, 6120-6123.

22. Alexander, R.T.; Woudenberg-Vrenken, T.E.; Buurman, J.; Dijkman, H.; van der Eerden, B.C.; van Leeuwen, J.P.; Bindels, R.J.; Hoenderop, J.G. Klotho prevents renal calcium loss. J. Am. Soc. Nephrol. 2009, 20, 2371-2379.

23. Kurosu, H.; Yamamoto, M.; Clark, J.D.; Pastor, J.V.; Nandi, A.; Gurnani, P.; McGuinness, O.P.; Chikuda, H.; Yamaguchi, M.; Kawaguchi, H.; et al. Suppression of aging in mice by the hormone Klotho. Science 2005, 309, 1829-1833.

24. Yamamoto, M.; Clark, J.D.; Pastor, J.V.; Gurnani, P.; Nandi, A.; Kurosu, H.; Miyoshi, M.; Ogawa, Y.; Castrillon, D.H.; Rosenblatt, K.P.; Kuro-o, M. Regulation of oxidative stress by the anti-aging hormone klotho. J. Biol. Chem. 2005, 280, 38029-38034.

25. Maekawa, Y.; Ishikawa, K.; Yasuda, O.; Oguro, R.; Hanasaki, H.; Kida, I.; Takemura, Y.; Ohishi, M.; Katsuya, T.; Rakugi, H. Klotho suppresses TNF-alpha-induced expression of adhesion molecules in the endothelium and attenuates NF-kappaB activation. Endocrine 2009, $35,341-346$.

26. Sugiura, H.; Yoshida, T.; Shiohira, S.; Kohei, J.; Mitobe, M.; Kurosu, H.; Kuro-o, M.; Nitta, K.; Tsuchiya, K. Reduced Klotho expression level in kidney aggravates renal interstitial fibrosis. Am. J. Physiol. Renal Physiol. 2012, 302, F1252-F1264.

27. Kim, H.R.; Nam, B.Y.; Kim, D.W.; Kang, M.W.; Han, J.H.; Lee, M.J.; Shin, D.H.; Doh, F.M.; Koo, H.M.; Ko, K.I.; et al. Circulating alpha-Klotho Levels in CKD and Relationship to Progression. Am. J. Kidney Dis. 2013, 61, 899-909.

28. Stubbs, J.R.; He, N.; Idiculla, A.; Gillihan, R.; Liu, S.; David, V.; Hong, Y.; Quarles, L.D. Longitudinal evaluation of FGF23 changes and mineral metabolism abnormalities in a mouse model of chronic kidney disease. J. Bone Miner. Res. 2012, 27, 38-46. 
29. Tsuruoka, S.; Nishiki, K.; Ioka, T.; Ando, H.; Saito, Y.; Kurabayashi, M.; Nagai, R.; Fujimura, A. Defect in parathyroid-hormone-induced luminal calcium absorption in connecting tubules of Klotho mice. Nephrol. Dial. Transpl. 2006, 21, 2762-2767.

30. Fliser, D.; Kollerits, B.; Neyer, U.; Ankerst, D.P.; Lhotta, K.; Lingenhel, A.; Ritz, E.; Kronenberg, F.; Kuen, E.; Konig, P.; et al. Fibroblast growth factor 23 (FGF23) predicts progression of chronic kidney disease: The Mild to Moderate Kidney Disease (MMKD) Study. J. Am. Soc. Nephrol. 2007, 18, 2600-2608.

31. Spiegel, D.M.; Brady, K. Calcium balance in normal individuals and in patients with chronic kidney disease on low- and high-calcium diets. Kidney Int. 2012, 81, 1116-1122.

32. Foley, R.N.; Collins, A.J.; Ishani, A.; Kalra, P.A. Calcium-phosphate levels and cardiovascular disease in community-dwelling adults: The Atherosclerosis Risk in Communities (ARIC) Study. Am. Heart J. 2008, 156, 556-563.

33. Bolland, M.J.; Grey, A.; Avenell, A.; Gamble, G.D.; Reid, I.R. Calcium supplements with or without vitamin D and risk of cardiovascular events: Reanalysis of the Women's Health Initiative limited access dataset and meta-analysis. BMJ 2011, 342, d2040.

34. Xiao, Q.; Murphy, R.A.; Houston, D.K.; Harris, T.B.; Chow, W.H.; Park, Y. Dietary and Supplemental Calcium Intake and Cardiovascular Disease Mortality: The National Institutes of Health-AARP Diet and Health Study. JAMA Intern. Med. 2013, 173, 639-646.

35. Reid, I.R.; Schooler, B.A.; Hannan, S.F.; Ibbertson, H.K. The acute biochemical effects of four proprietary calcium preparations. Aust. N. Z. J. Med. 1986, 16, 193-197.

36. Michaëlsson, K.; Melhus, H.; Lemming, E.W.; Wolk, A.; Byberg, L. Long term calcium intake and rates of all cause and cardiovascular mortality: Community based prospective longitudinal cohort study. BMJ 2013, 346, f228.

37. Ginde, A.A.; Scragg, R.; Schwartz, R.S.; Camargo, C.A., Jr. Prospective study of serum 25-hydroxyvitamin D level, cardiovascular disease mortality, and all-cause mortality in older U.S. adults. J. Am. Geriatr. Soc. 2009, 57, 1595-1603.

38. Cauley, J.A.; Thompson, D.E.; Ensrud, K.C.; Scott, J.C.; Black, D. Risk of mortality following clinical fractures. Osteoporos Int. 2000, 11, 556-561.

39. Aishah, A.B.; Foo, Y.N. A retrospective study of serum calcium levels in a hospital population in Malaysia. Med. J. Malaysia 1995, 50, 246-249.

40. Hastbacka, J.; Pettila, V. Prevalence and predictive value of ionized hypocalcemia among critically ill patients. Acta Anaesthesiol. Scand. 2003, 47, 1264-1269.

41. Kolb, J.P.; Schilling, A.F.; Bischoff, J.; Novo de Oliveira, A.; Spiro, A.; Hoffmann, M.; Amling, M.; Rueger, J.M.; Lehmann, W. Calcium homeostasis influences radiological fracture healing in postmenopausal women. Arch. Orthop. Trauma Surg. 2012, 133, 187-192.

42. Fatayerji, D.; Mawer, E.B.; Eastell, R. The role of insulin-like growth factor I in age-related changes in calcium homeostasis in men. J. Clin. Endocrinol. Metab. 2000, 85, 4657-4662.

43. Levin, A.; Bakris, G.L.; Molitch, M.; Smulders, M.; Tian, J.; Williams, L.A.; Andress, D.L. Prevalence of abnormal serum vitamin D, PTH, calcium, and phosphorus in patients with chronic kidney disease: Results of the study to evaluate early kidney disease. Kidney Int. 2007, 71, 31-38. 
44. Vassalotti, J.A.; Uribarri, J.; Chen, S.C.; Li, S.; Wang, C.; Collins, A.J.; Calvo, M.S.; Whaley-Connell, A.T.; McCullough, P.A.; Norris, K.C. Trends in mineral metabolism: Kidney Early Evaluation Program (KEEP) and the National Health and Nutrition Examination Survey (NHANES) 1999-2004. Am. J. Kidney Dis. 2008, 51, S56-S68.

45. Markowitz, G.S.; Perazella, M.A. Acute phosphate nephropathy. Kidney Int. 2009, 76, $1027-1034$.

46. Gutierrez, O.; Isakova, T.; Rhee, E.; Shah, A.; Holmes, J.; Collerone, G.; Juppner, H.; Wolf, M. Fibroblast growth factor-23 mitigates hyperphosphatemia but accentuates calcitriol deficiency in chronic kidney disease. J. Am. Soc. Nephrol. 2005, 16, 2205-2215.

47. Moranne, O.; Froissart, M.; Rossert, J.; Gauci, C.; Boffa, J.J.; Haymann, J.P.; M'Rad, M.B.; Jacquot, C.; Houillier, P.; Stengel, B.; Fouqueray, B. Timing of onset of CKD-related metabolic complications. J. Am. Soc. Nephrol. 2009, 20, 164-171.

48. Cannata-Andia, J.B.; Naves-Diaz, M. Phosphorus and survival: Key questions that need answers. J. Am. Soc. Nephrol. 2009, 20, 234-236.

49. Mathew, S.; Tustison, K.S.; Sugatani, T.; Chaudhary, L.R.; Rifas, L.; Hruska, K.A. The mechanism of phosphorus as a cardiovascular risk factor in CKD. J. Am. Soc. Nephrol. 2008, 19, 1092-1105.

50. Kendrick, J.; Chonchol, M. The role of phosphorus in the development and progression of vascular calcification. Am. J. Kidney Dis. 2011, 58, 826-834.

51. Ix, J.H.; De Boer, I.H.; Peralta, C.A.; Adeney, K.L.; Duprez, D.A.; Jenny, N.S.; Siscovick, D.S.; Kestenbaum, B.R. Serum phosphorus concentrations and arterial stiffness among individuals with normal kidney function to moderate kidney disease in MESA. Clin. J. Am. Soc. Nephrol. 2009, 4, 609-615.

52. Dhingra, R.; Sullivan, L.M.; Fox, C.S.; Wang, T.J.; D’Agostino, R.B., Sr.; Gaziano, J.M.; Vasan, R.S. Relations of serum phosphorus and calcium levels to the incidence of cardiovascular disease in the community. Arch. Intern. Med. 2007, 167, 879-885.

53. Kestenbaum, B.; Sampson, J.N.; Rudser, K.D.; Patterson, D.J.; Seliger, S.L.; Young, B.; Sherrard, D.J.; Andress, D.L. Serum phosphate levels and mortality risk among people with chronic kidney disease. J. Am. Soc. Nephrol. 2005, 16, 520-528.

54. Ohnishi, M.; Razzaque, M.S. Dietary and genetic evidence for phosphate toxicity accelerating mammalian aging. FASEB J. 2010, 24, 3562-3571.

55. Robinson, J.K. Sun exposure, sun protection, and vitamin D. JAMA 2005, 294, 1541-1543.

56. Holick, M.F. The vitamin D epidemic and its health consequences. J. Nutr. 2005, 135, 2739S-2748S.

57. Bosworth, C.R.; Levin, G.; Robinson-Cohen, C.; Hoofnagle, A.N.; Ruzinski, J.; Young, B.; Schwartz, S.M.; Himmelfarb, J.; Kestenbaum, B.; de Boer, I.H. The serum 24,25-dihydroxyvitamin D concentration, a marker of vitamin D catabolism, is reduced in chronic kidney disease. Kidney Int. 2012, 82, 693-700.

58. Carlberg, C.; Bendik, I.; Wyss, A.; Meier, E.; Sturzenbecker, L.J.; Grippo, J.F.; Hunziker, W. Two nuclear signalling pathways for vitamin D. Nature 1993, 361, 657-660. 
59. Haussler, M.R.; Jurutka, P.W.; Mizwicki, M.; Norman, A.W. Vitamin D receptor (VDR)-mediated actions of 1alpha,25(OH)(2)vitamin $\mathrm{D}(3)$ : Genomic and non-genomic mechanisms. Best Pract. Res. Clin. Endocrinol. Metab. 2011, 25, 543-559.

60. Deb, D.K.; Sun, T.; Wong, K.E.; Zhang, Z.; Ning, G.; Zhang, Y.; Kong, J.; Shi, H.; Chang, A.; Li, Y.C. Combined vitamin D analog and AT1 receptor antagonist synergistically block the development of kidney disease in a model of type 2 diabetes. Kidney Int. 2010, 77, 1000-1009.

61. Vaidya, A.; Forman, J.P.; Williams, J.S. Vitamin D and the vascular sensitivity to angiotensin II in obese Caucasians with hypertension. J. Hum. Hypertens. 2011, 25, 672-678.

62. Ohara, I.; Tanimoto, M.; Gohda, T.; Yamazaki, T.; Hagiwara, S.; Murakoshi, M.; Aoki, T.; Toyoda, H.; Ishikawa, Y.; Funabiki, K.; et al. Effect of combination therapy with angiotensin receptor blocker and 1,25-dihydroxyvitamin $\mathrm{D}(3)$ in type 2 diabetic nephropathy in KK-A(y)/Ta mice. Nephron Exp. Nephrol. 2011, 117, e124-e132.

63. Vaidya, A.; Sun, B.; Larson, C.; Forman, J.P.; Williams, J.S. Vitamin D3 therapy corrects the tissue sensitivity to angiotensin II akin to the action of a converting enzyme inhibitor in obese hypertensives: An interventional study. J. Clin. Endocrinol. Metab. 2012, 97, 2456-2465.

64. Martini, L.A.; Wood, R.J. Milk intake and the risk of type 2 diabetes mellitus, hypertension and prostate cancer. Arq. Bras. Endocrinol. Metabol. 2009, 53, 688-694.

65. Gorham, E.D.; Garland, C.F.; Burgi, A.A.; Mohr, S.B.; Zeng, K.; Hofflich, H.; Kim, J.J.; Ricordi, C. Lower prediagnostic serum 25-hydroxyvitamin D concentration is associated with higher risk of insulin-requiring diabetes: A nested case-control study. Diabetologia 2012, 55, 3224-3227.

66. van der Rhee, H.; Coebergh, J.W.; de Vries, E. Is prevention of cancer by sun exposure more than just the effect of vitamin D? A systematic review of epidemiological studies. Eur. J. Cancer 2012, 49, 1422-1436.

67. Bergman, P.; Norlin, A.C.; Hansen, S.; Rekha, R.S.; Agerberth, B.; Bjorkhem-Bergman, L.; Ekstrom, L.; Lindh, J.D.; Andersson, J. Vitamin D3 supplementation in patients with frequent respiratory tract infections: A randomised and double-blind intervention study. BMJ Open 2012, 2, e001663.

68. Balion, C.; Griffith, L.E.; Strifler, L.; Henderson, M.; Patterson, C.; Heckman, G.; Llewellyn, D.J.; Raina, P. Vitamin D, cognition, and dementia: A systematic review and meta-analysis. Neurology 2012, 79, 1397-1405.

69. Mizwicki, M.T.; Menegaz, D.; Zhang, J.; Barrientos-Duran, A.; Tse, S.; Cashman, J.R.; Griffin, P.R.; Fiala, M. Genomic and nongenomic signaling induced by 1alpha,25(OH)2-vitamin D3 promotes the recovery of amyloid-beta phagocytosis by Alzheimer's disease macrophages. J. Alzheimers Dis. 2012, 29, 51-62.

70. Autier, P.; Gandini, S. Vitamin D supplementation and total mortality: A meta-analysis of randomized controlled trials. Arch. Intern. Med. 2007, 167, 1730-1737.

71. de Boer, I.H.; Levin, G.; Robinson-Cohen, C.; Biggs, M.L.; Hoofnagle, A.N.; Siscovick, D.S.; Kestenbaum, B. Serum 25-hydroxyvitamin D concentration and risk for major clinical disease events in a community-based population of older adults: A cohort study. Ann. Intern. Med. 2012, $156,627-634$. 
72. Teng, M.; Wolf, M.; Lowrie, E.; Ofsthun, N.; Lazarus, J.M.; Thadhani, R. Survival of patients undergoing hemodialysis with paricalcitol or calcitriol therapy. N. Engl. J. Med. 2003, 349, 446-456.

73. Bischoff-Ferrari, H.A.; Shao, A.; Dawson-Hughes, B.; Hathcock, J.; Giovannucci, E.; Willett, W.C. Benefit-risk assessment of vitamin D supplementation. Osteoporos. Int. 2010, 21, 1121-1132.

74. Holick, M.F. Vitamin D deficiency. N. Engl. J. Med. 2007, 357, 266-281.

75. Wang, L.; Song, Y.; Manson, J.E.; Pilz, S.; Marz, W.; Michaelsson, K.; Lundqvist, A.; Jassal, S.K.; Barrett-Connor, E.; Zhang, C.; et al. Circulating 25-hydroxy-vitamin D and risk of cardiovascular disease: A meta-analysis of prospective studies. Circ. Cardiovasc. Qual. Outcomes 2012, 5, 819-829.

76. Holick, M.F. Vitamin D status: Measurement, interpretation, and clinical application. Ann. Epidemiol. 2009, 19, 73-78.

77. Forrest, K.Y.; Stuhldreher, W.L. Prevalence and correlates of vitamin D deficiency in US adults. Nutr. Res. 2011, 31, 48-54.

78. Janssen, H.C.; Emmelot-Vonk, M.H.; Verhaar, H.J.; van der Schouw, Y.T. Determinants of vitamin D status in healthy men and women aged 40-80 years. Maturitas 2013, 74, 79-83.

79. MacLaughlin, J.; Holick, M.F. Aging decreases the capacity of human skin to produce vitamin D3. J. Clin. Invest. 1985, 76, 1536-1538.

80. Ebeling, P.R.; Sandgren, M.E.; DiMagno, E.P.; Lane, A.W.; DeLuca, H.F.; Riggs, B.L. Evidence of an age-related decrease in intestinal responsiveness to vitamin D: Relationship between serum 1,25-dihydroxyvitamin D3 and intestinal vitamin D receptor concentrations in normal women. J. Clin. Endocrinol. Metab. 1992, 75, 176-182.

81. Tsiaras, W.G.; Weinstock, M.A. Factors influencing vitamin D status. Acta Derm. Venereol. 2011, 91, 115-124.

82. Pilz, S.; Iodice, S.; Zittermann, A.; Grant, W.B.; Gandini, S. Vitamin D status and mortality risk in CKD: A meta-analysis of prospective studies. Am. J. Kidney Dis. 2011, 58, 374-382.

83. Bischoff-Ferrari, H.A.; Willett, W.C.; Orav, E.J.; Lips, P.; Meunier, P.J.; Lyons, R.A.; Flicker, L.; Wark, J.; Jackson, R.D.; Cauley, J.A.; et al. A pooled analysis of vitamin D dose requirements for fracture prevention. N. Engl. J. Med. 2012, 367, 40-49.

84. de Zeeuw, D.; Agarwal, R.; Amdahl, M.; Audhya, P.; Coyne, D.; Garimella, T.; Parving, H.H.; Pritchett, Y.; Remuzzi, G.; Ritz, E.; Andress, D. Selective vitamin D receptor activation with paricalcitol for reduction of albuminuria in patients with type 2 diabetes (VITAL study): A randomised controlled trial. Lancet 2010, 376, 1543-1551.

85. Verhave, G.; Siegert, C.E. Role of vitamin D in cardiovascular disease. Neth. J. Med. 2010, 68, 113-118.

86. Rejnmark, L.; Avenell, A.; Masud, T.; Anderson, F.; Meyer, H.E.; Sanders, K.M.; Salovaara, K.; Cooper, C.; Smith, H.E.; Jacobs, E.T.; et al. Vitamin D with calcium reduces mortality: Patient level pooled analysis of 70,528 patients from eight major vitamin D trials. J. Clin. Endocrinol. Metab. 2012, 97, 2670-2681. 
87. Shoben, A.B.; Rudser, K.D.; de Boer, I.H.; Young, B.; Kestenbaum, B. Association of oral calcitriol with improved survival in nondialyzed CKD. J. Am. Soc. Nephrol. 2008, 19, 1613-1619.

88. Teng, M.; Wolf, M.; Ofsthun, M.N.; Lazarus, J.M.; Hernan, M.A.; Camargo, C.A., Jr.; Thadhani, R. Activated injectable vitamin D and hemodialysis survival: A historical cohort study. J. Am. Soc. Nephrol. 2005, 16, 1115-1125.

89. Brondum-Jacobsen, P.; Benn, M.; Jensen, G.B.; Nordestgaard, B.G. 25-hydroxyvitamin D levels and risk of ischemic heart disease, myocardial infarction, and early death: Population-based study and meta-analyses of 18 and 17 studies. Arterioscler. Thromb. Vasc. Biol. 2012, 32, 2794-2802.

90. Lau, W.L.; Leaf, E.M.; Hu, M.C.; Takeno, M.M.; Kuro-o, M.; Moe, O.W.; Giachelli, C.M. Vitamin D receptor agonists increase klotho and osteopontin while decreasing aortic calcification in mice with chronic kidney disease fed a high phosphate diet. Kidney Int. 2012, 82, 1261-1270.

91. Segre, G.V.; D’Amour, P.; Hultman, A.; Potts, J.T., Jr. Effects of hepatectomy, nephrectomy, and nephrectomy/uremia on the metabolism of parathyroid hormone in the rat. J. Clin. Invest. 1981, 67, 439-448.

92. D'Amour, P.; Lazure, C. Metabolism of radioiodinated carboxy-terminal fragments of bovine parathyroid hormone in normal and anephric rats. Endocrinology 1985, 117, 127-134.

93. Brown, E.M.; Gamba, G.; Riccardi, D.; Lombardi, M.; Butters, R.; Kifor, O.; Sun, A.; Hediger, M.A.; Lytton, J.; Hebert, S.C. Cloning and characterization of an extracellular $\mathrm{Ca}(2+)$-sensing receptor from bovine parathyroid. Nature 1993, 366, 575-580.

94. Egbuna, O.I.; Brown, E.M. Hypercalcaemic and hypocalcaemic conditions due to calcium-sensing receptor mutations. Best Pract. Res. Clin. Rheumatol. 2008, 22, 129-148.

95. Ritter, C.S.; Brown, A.J. Direct suppression of Pth gene expression by the vitamin D prohormones doxercalciferol and calcidiol requires the vitamin D receptor. J. Mol. Endocrinol. 2011, 46, 63-66.

96. Lavi-Moshayoff, V.; Wasserman, G.; Meir, T.; Silver, J.; Naveh-Many, T. PTH increases FGF23 gene expression and mediates the high-FGF23 levels of experimental kidney failure: A bone parathyroid feedback loop. Am. J. Physiol. Renal Physiol. 2010, 299, F882-F889.

97. Ganong, W.F.; Barrett, K.E. Ganong's Review of Medical Physiology, 24th ed.; Barrett, K.E., Boitano, S., Barman, S.M., Brooks, H.L., Eds.; McGraw-Hill: New York, NY, USA; p. 752.

98. Ferrari, S.L.; Bonjour, J.P.; Rizzoli, R. Fibroblast growth factor-23 relationship to dietary phosphate and renal phosphate handling in healthy young men. J. Clin. Endocrinol. Metab. 2005, 90, 1519-1524.

99. Westerberg, P.A.; Ljunggren, O.; Larsson, T.E.; Wadstrom, J.; Linde, T. Fibroblast growth factor-23 and mineral metabolism after unilateral nephrectomy. Nephrol. Dial. Transpl. 2010, $25,4068-4071$.

100. Shimada, T.; Hasegawa, H.; Yamazaki, Y.; Muto, T.; Hino, R.; Takeuchi, Y.; Fujita, T.; Nakahara, K.; Fukumoto, S.; Yamashita, T. FGF-23 is a potent regulator of vitamin D metabolism and phosphate homeostasis. J. Bone Miner. Res. 2004, 19, 429-435.

101. Heath, H.; Hodgson, S.F.; Kennedy, M.A. Primary Hyperparathyroidism. N. Engl. J. Med. 1980, 302, 189-193. 
102. Block, G.A.; Martin, K.J.; de Francisco, A.L.; Turner, S.A.; Avram, M.M.; Suranyi, M.G.; Hercz, G.; Cunningham, J.; Abu-Alfa, A.K.; Messa, P.; et al. Cinacalcet for secondary hyperparathyroidism in patients receiving hemodialysis. N. Engl. J. Med. 2004, 350, 1516-1525.

103. Urena, P.; Bernard-Poenaru, O.; Cohen-Solal, M.; de Vernejoul, M.C. Plasma bone-specific alkaline phosphatase changes in hemodialysis patients treated by alfacalcidol. Clin. Nephrol. 2002, 57, 261-273.

104. Goodman, W.G.; Ramirez, J.A.; Belin, T.R.; Chon, Y.; Gales, B.; Segre, G.V.; Salusky, I.B. Development of adynamic bone in patients with secondary hyperparathyroidism after intermittent calcitriol therapy. Kidney Int. 1994, 46, 1160-1166.

105. Yamashita, T.; Yoshioka, M.; Itoh, N. Identification of a novel fibroblast growth factor, FGF-23, preferentially expressed in the ventrolateral thalamic nucleus of the brain. Biochem. Biophys. Res. Commun. 2000, 277, 494-498.

106. Liu, S.; Zhou, J.; Tang, W.; Jiang, X.; Rowe, D.W.; Quarles, L.D. Pathogenic role of Fgf23 in Hyp mice. Am. J. Physiol. Endocrinol. Metab. 2006, 291, E38-E49.

107. Kumar, R. Phosphatonin - a new phosphaturetic hormone? (lessons from tumour-induced osteomalacia and X-linked hypophosphataemia). Nephrol. Dial. Transpl. 1997, 12, 11-13.

108. Canalejo, R.; Canalejo, A.; Martinez-Moreno, J.M.; Rodriguez-Ortiz, M.E.; Estepa, J.C.; Mendoza, F.J.; Munoz-Castaneda, J.R.; Shalhoub, V.; Almaden, Y.; Rodriguez, M. FGF23 fails to inhibit uremic parathyroid glands. J. Am. Soc. Nephrol. 2010, 21, 1125-1135.

109. Stubbs, J.R.; Egwuonwu, S. Is fibroblast growth factor 23 a harbinger of mortality in CKD? Pediatr. Nephrol. 2012, 27, 697-703.

110. Mak, M.P.; da Costa e Silva, V.T.; Martin, R.M.; Lerario, A.M.; Yu, L.; Hoff, P.M.; de Castro, G., Jr. Advanced prostate cancer as a cause of oncogenic osteomalacia: An underdiagnosed condition. Support Care Cancer 2012, 20, 2195-2197.

111. Folpe, A.L.; Fanburg-Smith, J.C.; Billings, S.D.; Bisceglia, M.; Bertoni, F.; Cho, J.Y.; Econs, M.J.; Inwards, C.Y.; Jan de Beur, S.M.; Mentzel, T.; et al. Most osteomalacia-associated mesenchymal tumors are a single histopathologic entity: An analysis of 32 cases and a comprehensive review of the literature. Am. J. Surg. Pathol. 2004, 28, 1-30.

112. Bai, X.Y.; Miao, D.; Goltzman, D.; Karaplis, A.C. The autosomal dominant hypophosphatemic rickets R176Q mutation in fibroblast growth factor 23 resists proteolytic cleavage and enhances in vivo biological potency. J. Biol. Chem. 2003, 278, 9843-9849.

113. Benet-Pages, A.; Orlik, P.; Strom, T.M.; Lorenz-Depiereux, B. An FGF23 missense mutation causes familial tumoral calcinosis with hyperphosphatemia. Hum. Mol. Genet. 2005, 14, 385-390.

114. Gutierrez, O.M.; Januzzi, J.L.; Isakova, T.; Laliberte, K.; Smith, K.; Collerone, G.; Sarwar, A.; Hoffmann, U.; Coglianese, E.; Christenson, R.; et al. Fibroblast growth factor 23 and left ventricular hypertrophy in chronic kidney disease. Circulation 2009, 119, 2545-2552.

115. Faul, C.; Amaral, A.P.; Oskouei, B.; Hu, M.C.; Sloan, A.; Isakova, T.; Gutierrez, O.M.; Aguillon-Prada, R.; Lincoln, J.; Hare, J.M.; et al. FGF23 induces left ventricular hypertrophy. J. Clin. Invest. 2011, 121, 4393-4408.

116. Gutierrez, O.M.; Mannstadt, M.; Isakova, T.; Rauh-Hain, J.A.; Tamez, H.; Shah, A.; Smith, K.; Lee, H.; Thadhani, R.; Juppner, H.; Wolf, M. Fibroblast growth factor 23 and mortality among patients undergoing hemodialysis. N. Engl. J. Med. 2008, 359, 584-592. 
117. Jean, G.; Terrat, J.C.; Vanel, T.; Hurot, J.M.; Lorriaux, C.; Mayor, B.; Chazot, C. High levels of serum fibroblast growth factor (FGF)-23 are associated with increased mortality in long haemodialysis patients. Nephrol. Dial. Transpl. 2009, 24, 2792-2796.

118. Hasegawa, H.; Nagano, N.; Urakawa, I.; Yamazaki, Y.; Iijima, K.; Fujita, T.; Yamashita, T.; Fukumoto, S.; Shimada, T. Direct evidence for a causative role of FGF23 in the abnormal renal phosphate handling and vitamin D metabolism in rats with early-stage chronic kidney disease. Kidney Int. 2010, 78, 975-980.

119. Shalhoub, V.; Shatzen, E.M.; Ward, S.C.; Davis, J.; Stevens, J.; Bi, V.; Renshaw, L.; Hawkins, N.; Wang, W.; Chen, C.; et al. FGF23 neutralization improves chronic kidney disease-associated hyperparathyroidism yet increases mortality. J. Clin. Invest. 2012, 122, 2543-2553.

120. Brown, A.J.; Zhong, M.; Finch, J.; Ritter, C.; McCracken, R.; Morrissey, J.; Slatopolsky, E. Rat calcium-sensing receptor is regulated by vitamin D but not by calcium. Am. J. Physiol. 1996, 270, F454-F460.

121. Dvorak, M.M.; Chen, T.H.; Orwoll, B.; Garvey, C.; Chang, W.; Bikle, D.D.; Shoback, D.M. Constitutive activity of the osteoblast $\mathrm{Ca}^{2+}$-sensing receptor promotes loss of cancellous bone. Endocrinology 2007, 148, 3156-3163.

122. Pollak, M.R.; Brown, E.M.; Estep, H.L.; McLaine, P.N.; Kifor, O.; Park, J.; Hebert, S.C.; Seidman, C.E.; Seidman, J.G. Autosomal dominant hypocalcaemia caused by a $\mathrm{Ca}(2+)$-sensing receptor gene mutation. Nat. Genet. 1994, 8, 303-307.

123. Theman, T.A.; Collins, M.T.; Dempster, D.W.; Zhou, H.; Reynolds, J.C.; Brahim, J.S.; Roschger, P.; Klaushofer, K.; Winer, K.K. PTH(1-34) replacement therapy in a child with hypoparathyroidism caused by a sporadic calcium receptor mutation. J. Bone Miner. Res. 2009, 24, 964-973.

124. Toke, J.; Czirjak, G.; Patocs, A.; Enyedi, B.; Gergics, P.; Csakvary, V.; Enyedi, P.; Toth, M. Neonatal severe hyperparathyroidism associated with a novel de novo heterozygous R551K inactivating mutation and a heterozygous A986S polymorphism of the calcium-sensing receptor gene. Clin. Endocrinol. (Oxf.) 2007, 67, 385-392.

125. Pollak, M.R.; Brown, E.M.; Chou, Y.H.; Hebert, S.C.; Marx, S.J.; Steinmann, B.; Levi, T.; Seidman, C.E.; Seidman, J.G. Mutations in the human $\mathrm{Ca}(2+)$-sensing receptor gene cause familial hypocalciuric hypercalcemia and neonatal severe hyperparathyroidism. Cell 1993, 75, 1297-1303.

126. Chang, W.; Rodriguez, L.; Chen, T.H.; Tu, C.; Shoback, D. Extracellular $\mathrm{Ca}^{2+}$-sensing in cartilage. J. Musculoskelet. Neuronal Interact. 2004, 4, 410-411.

127. Moe, S.; Drueke, T.; Cunningham, J.; Goodman, W.; Martin, K.; Olgaard, K.; Ott, S.; Sprague, S.; Lameire, N.; Eknoyan, G. Definition, evaluation, and classification of renal osteodystrophy: A position statement from Kidney Disease: Improving Global Outcomes (KDIGO). Kidney Int. 2006, 69, 1945-1953.

128. Joy, M.S.; Karagiannis, P.C.; Peyerl, F.W. Outcomes of secondary hyperparathyroidism in chronic kidney disease and the direct costs of treatment. J. Manag. Care Pharm. 2007, 13, 397-411. 
129. Suda, T.; Takahashi, N.; Udagawa, N.; Jimi, E.; Gillespie, M.T.; Martin, T.J. Modulation of osteoclast differentiation and function by the new members of the tumor necrosis factor receptor and ligand families. Endocr. Rev. 1999, 20, 345-357.

130. Itoh, K.; Udagawa, N.; Matsuzaki, K.; Takami, M.; Amano, H.; Shinki, T.; Ueno, Y.; Takahashi, N.; Suda, T. Importance of membrane- or matrix-associated forms of M-CSF and RANKL/ODF in osteoclastogenesis supported by SaOS-4/3 cells expressing recombinant PTH/PTHrP receptors. J. Bone Miner. Res. 2000, 15, 1766-1775.

131. Kanzawa, M.; Sugimoto, T.; Kanatani, M.; Chihara, K. Involvement of osteoprotegerin/ osteoclastogenesis inhibitory factor in the stimulation of osteoclast formation by parathyroid hormone in mouse bone cells. Eur. J. Endocrinol. 2000, 142, 661-664.

132. Jara, A.; Bover, J.; Felsenfeld, A.J. Development of secondary hyperparathyroidism and bone disease in diabetic rats with renal failure. Kidney Int. 1995, 47, 1746-1751.

133. Couttenye, M.M.; D’Haese, P.C.; Deng, J.T.; van Hoof, V.O.; Verpooten, G.A.; de Broe, M.E. High prevalence of adynamic bone disease diagnosed by biochemical markers in a wide sample of the European CAPD population. Nephrol. Dial. Transpl. 1997, 12, 2144-2150.

134. Cannata-Andia, J.B.; Rodriguez Garcia, M.; Gomez Alonso, C. Osteoporosis and adynamic bone in chronic kidney disease. J. Nephrol. 2013, 26, 73-80.

135. Block, G.A.; Port, F.K. Re-evaluation of risks associated with hyperphosphatemia and hyperparathyroidism in dialysis patients: Recommendations for a change in management. Am. J. Kidney Dis. 2000, 35, 1226-1237.

136. Kidney Disease: Improving Global Outcomes (KDIGO) CKD-MBD Work Group. KDIGO clinical practice guideline for the diagnosis, evaluation, prevention, and treatment of Chronic Kidney Disease-Mineral and Bone Disorder (CKD-MBD). Kidney Int. Suppl. 2009, 113, S1-S130.

137. Kazama, J.J.; Koda, R.; Yamamoto, S.; Narita, I.; Gejyo, F.; Tokumoto, A. Cancellous bone volume is an indicator for trabecular bone connectivity in dialysis patients. Clin. J. Am. Soc. Nephrol. 2010, 5, 292-298.

138. Malluche, H.H.; Monier-Faugere, M.C. Renal osteodystrophy: What's in a name? Presentation of a clinically useful new model to interpret bone histologic findings. Clin. Nephrol. 2006, 65, 235-242.

139. Mac Way, F.; Lessard, M.; Lafage-Proust, M.H. Pathophysiology of chronic kidney disease-mineral and bone disorder. Joint Bone Spine 2012, 79, 544-549.

140. Reeve, J.; Arlot, M.E.; Chavassieux, P.M.; Edouard, C.; Green, J.R.; Hesp, R.; Tellez, M.; Meunier, P.J. The assessment of bone formation and bone resorption in osteoporosis: A comparison between tetracycline-based iliac histomorphometry and whole body $85 \mathrm{Sr}$ kinetics. J. Bone Miner. Res. 1987, 2, 479-489.

141. Kiel, D.P.; Kauppila, L.I.; Cupples, L.A.; Hannan, M.T.; O’Donnell, C.J.; Wilson, P.W. Bone loss and the progression of abdominal aortic calcification over a 25 year period: The Framingham Heart Study. Calcif. Tissue Int. 2001, 68, 271-276.

142. Naves, M.; Rodriguez-Garcia, M.; Diaz-Lopez, J.B.; Gomez-Alonso, C.; Cannata-Andia, J.B. Progression of vascular calcifications is associated with greater bone loss and increased bone fractures. Osteoporos. Int. 2008, 19, 1161-1166. 
143. Rodriguez Garcia, M.; Naves Diaz, M.; Cannata Andia, J.B. Bone metabolism, vascular calcifications and mortality: Associations beyond mere coincidence. J. Nephrol. 2005, 18, 458-463.

144. Sigrist, M.; Bungay, P.; Taal, M.W.; McIntyre, C.W. Vascular calcification and cardiovascular function in chronic kidney disease. Nephrol. Dial. Transpl. 2006, 21, 707-714.

145. Merjanian, R.; Budoff, M.; Adler, S.; Berman, N.; Mehrotra, R. Coronary artery, aortic wall, and valvular calcification in nondialyzed individuals with type 2 diabetes and renal disease. Kidney Int. 2003, 64, 263-271.

146. Goodman, W.G.; Goldin, J.; Kuizon, B.D.; Yoon, C.; Gales, B.; Sider, D.; Wang, Y.; Chung, J.; Emerick, A.; Greaser, L.; et al. Coronary-artery calcification in young adults with end-stage renal disease who are undergoing dialysis. N. Engl. J. Med. 2000, 342, 1478-1483.

147. Stenvinkel, P. Chronic kidney disease: A public health priority and harbinger of premature cardiovascular disease. J. Intern. Med. 2010, 268, 456-467.

148. Stenvinkel, P.; Larsson, T.E. Chronic Kidney Disease: A Clinical Model of Premature Aging Am. J. Kidney Dis. 2013, in press. Avaiable online: http:/www.sciencedirect.com/science/ article/pii/S0272638612015922 (accessed on 15 May 2013).

149. Reynolds, J.L.; Joannides, A.J.; Skepper, J.N.; McNair, R.; Schurgers, L.J.; Proudfoot, D.; Jahnen-Dechent, W.; Weissberg, P.L.; Shanahan, C.M. Human vascular smooth muscle cells undergo vesicle-mediated calcification in response to changes in extracellular calcium and phosphate concentrations: A potential mechanism for accelerated vascular calcification in ESRD. J. Am. Soc. Nephrol. 2004, 15, 2857-2867.

150. Lim, K.; Lu, T.S.; Molostvov, G.; Lee, C.; Lam, F.T.; Zehnder, D.; Hsiao, L.L. Vascular Klotho deficiency potentiates the development of human artery calcification and mediates resistance to fibroblast growth factor 23. Circulation 2012, 125, 2243-2255.

151. Sigrist, M.K.; Taal, M.W.; Bungay, P.; McIntyre, C.W. Progressive vascular calcification over 2 years is associated with arterial stiffening and increased mortality in patients with stages 4 and 5 chronic kidney disease. Clin. J. Am. Soc. Nephrol. 2007, 2, 1241-1248.

152. Floege, J.; Kim, J.; Ireland, E.; Chazot, C.; Drueke, T.; de Francisco, A.; Kronenberg, F.; Marcelli, D.; Passlick-Deetjen, J.; Schernthaner, G.; et al. Serum iPTH, calcium and phosphate, and the risk of mortality in a European haemodialysis population. Nephrol. Dial. Transpl. 2011, 26, 1948-1955.

153. Block, G.A.; Wheeler, D.C.; Persky, M.S.; Kestenbaum, B.; Ketteler, M.; Spiegel, D.M.; Allison, M.A.; Asplin, J.; Smits, G.; Hoofnagle, A.N.; et al. Effects of phosphate binders in moderate CKD. J. Am. Soc. Nephrol. 2012, 23, 1407-1415.

154. Chue, C.D.; Townend, J.N.; Moody, W.E.; Zehnder, D.; Wall, N.A.; Harper, L.; Edwards, N.C.; Steeds, R.P.; Ferro, C.J. Cardiovascular Effects of Sevelamer in Stage 3 CKD. J. Am. Soc. Nephrol. 2013, 24, 842852.

155. Andress, D.L.; Coyne, D.W.; Kalantar-Zadeh, K.; Molitch, M.E.; Zangeneh, F.; Sprague, S.M. Management of secondary hyperparathyroidism in stages 3 and 4 chronic kidney disease. Endocr. Pract. 2008, 14, 18-27. 
156. Cunningham, J.; Danese, M.; Olson, K.; Klassen, P.; Chertow, G.M. Effects of the calcimimetic cinacalcet $\mathrm{HCl}$ on cardiovascular disease, fracture, and health-related quality of life in secondary hyperparathyroidism. Kidney Int. 2005, 68, 1793-1800.

157. Chertow, G.M.; Block, G.A.; Correa-Rotter, R.; Drueke, T.B.; Floege, J.; Goodman, W.G.; Herzog, C.A.; Kubo, Y.; London, G.M.; Mahaffey, K.W.; et al. Effect of cinacalcet on cardiovascular disease in patients undergoing dialysis. N. Engl. J. Med. 2012, 367, 2482-2494.

(C) 2013 by the authors; licensee MDPI, Basel, Switzerland. This article is an open access article distributed under the terms and conditions of the Creative Commons Attribution license (http://creativecommons.org/licenses/by/3.0/). 